\title{
Potato Production in Kenya: Farming Systems and Production Constraints
}

\author{
Jane Muthoni ${ }^{1,2}$, Hussein Shimelis ${ }^{1} \&$ Rob Melis ${ }^{1}$ \\ ${ }^{1}$ African Centre for Crop Improvement, University of Kwa Zulu-Natal. College of Agriculture, Engineering and \\ Science, School of Agricultural, Earth and Environmental Sciences, Private Bag X01, Scottsxille 3209, \\ Pietermaritzburg, South Africa \\ ${ }^{2}$ Kenya Agricultural Research Institute (KARI). National Potato Research Centre, Tigoni, Kenya \\ Correspondence: Jane Muthoni, African Centre for Crop Improvement, University of Kwa Zulu-Natal. College of \\ Agriculture, Engineering and Science, School of Agricultural, Earth and Environmental Sciences, Private Bag \\ X01, Scottsxille 3209, Pietermaritzburg, South Africa. E-mail: jayney480@yahoo.com
}

Received: November 28, 2012 Accepted: January 8, 2013 Online Published: April 15, 2013

doi:10.5539/jas.v5n5p182 URL: http://dx.doi.org/10.5539/jas.v5n5p182

\begin{abstract}
Potato (Solanum tuberosum L.) is a major food and cash crop in the Kenyan highlands, widely grown by small-scale farmers. Farmer practices and constraints in potato production differ from region to region. A survey was conducted in three major potato producing districts namely Bomet, Molo and Meru Central with the following objectives: 1) to document farmers' practices, key potato production and marketing constraints, 2) to determine farmers' potato cultivar and trait preferences and 3 ) to assess the prevalence and farmers' management of bacterial wilt. The survey was carried out between November 2011 and March 2012. During the survey, a semi-structured questionnaire was administered to 253 individual farmers. The results show that the average household farm sizes are less than 2.4 hectares in all the districts. Majority of farmers allocate more than $25 \%$ of their farms to potatoes. Potato is produced both for food and cash by $90 \%$ of respondents in all districts. In Bomet district the red-skinned Dutch Robyjn is widely grown. In Molo district, the white- skinned Cangi is prominent while in Meru Central, the red-skinned Asante is predominantly grown by farmers. Cultivar preferences are mostly dictated by availability of markets, yield potential and taste. The major potato production constraints are diseases with bacterial wilt being the most prominent.
\end{abstract}

Keywords: bacterial wilt, farming systems, potato production constraints

\section{Introduction}

Potato (Solanum tuberosum L.) plays a major role in food security in Kenya and contributes to poverty alleviation through income generation and employment creation. Despite its importance, the potato sector is plagued by numerous problems such as a lack of clean seeds, lack of proper pest and disease management, a disorganised marketing system and a lack of clear policies on packaging (Riungu, 2011).

The shortage of clean (disease free) planting materials has led to low yields, poor quality produce, and spread of pests and diseases (GIZ-PSDA Kenya, 2011; Riungu, 2011). Kenya produces less than 1\% of the national certified seed demand. Because of shortage of clean planting materials, farmers are forced to plant seeds from informal sources such as farm-saved (self supply), local markets or neighbours. The informal system leads to the use of poor quality seeds and often accelerates the spread of seed-borne diseases such as bacterial wilt (Kinyua et al., 2001; Ng'ang'a et al., 2003). According to some studies, bacterial wilt has affected $77 \%$ of potato farms (Kaguongo et al., 2010). Because of the high prevalence of this disease, a strict rotation programme is required in the production of the crop; few farmers can rotate for the recommended one and a half years due to paucity of land (Riungu, 2011).

Control of bacterial wilt on potatoes is difficult and no single control method has been found to be totally effective (Champoiseau et al., 2009). The common approach in the management of the disease is an integrated combination of measures such as phytosanitation (use of disease-free seeds and quarantine), cultural practices (crop rotation, intercropping and delayed planting), chemical control and biological control (Martin \& French, 1985; Champoiseau et al., 2010). However, most of these measures have been found to be ineffective, impractical and/or 
expensive (Lemaga, 1997; Otipa et al., 2003; Kaguongo et al., 2008, 2010; Riungu, 2011). Host resistance could therefore offer a more lasting solution.

Disease resistance, in addition to other good traits, may increase the chances of a cultivar being adopted by farmers as this may reduce production costs. The various end-uses of potatoes require specific tuber characteristics and cultivars. In a previous study, it was found that attributes considered in ranking a potato cultivar by farmers are high yield potential, late blight resistance, taste, maturity period, market demand, bacterial wilt resistance, tuber size, and drought tolerance in that order (Kaguongo et al., 2008). In another study, it was found that farmers prefer cultivars for home consumption to be tasty, high yielding and resistant to late blight while the cultivars should have high market demand and be high yielding if they are destined for the market (McArthur, 1989). Tuber quality characteristics such as skin colour, tuber size, tuber shape and time to maturity are often key factors in cultivar acceptability based on local consumer preferences and criteria for potato processing (McArthur, 1989). Red-skinned cultivars, which are considered to boil quickly and mash easily are favoured for home consumption while white cultivars are preferred for making chips and french fries (McArthur, 1989). Different markets prefer different skin colour, tuber shape and sizes. For example, for making french fries, most processors in Kenya prefer the long white-skinned cultivars while the round red-skinned cultivars are preferred for making chips (Walingo et al., 1998). In addition, red-skinned cultivars have a greater demand in the fresh market probably because they do not turn green when exposed to the light as quickly as white-skinned cultivars. In Kenya, red-skinned cultivars were found to be more popular than the white-skinned ones in Meru Central district while the opposite was found in Nyandarua district (Kaguongo et al., 2008). Early maturity is important for food security and it enables households to generate income early to meet financial obligations. It is also an important trait in potato growing areas with a high demand for land as early harvesting allows more crop cycles in a year. In addition, the short rainy season is often erratic and an early maturing cultivar stands a better chance of carrying the crop to full maturity.

Over time some potato cultivars have been rejected and replaced by others in Kenya; low yield and susceptibility to diseases were cited as the major weaknesses. For instance, Kerr's Pink was removed from its dominant position in Meru Central by Ngure; the latter has been replaced by Asante and Tigoni Red (Durr \& Lorenzl, 1980; Crissman et al., 1993). Desiree has been largely abandoned due to low yield, poor market, poor taste and susceptibility to late blight (McArthur, 1989).

For a cultivar to be readily adopted, it must have farmer-preferred traits in addition to disease resistance. Without farmer participation either through participatory rural appraisal, participatory variety selection or participatory plant breeding (PPB), breeders often fail to target farmer-preferred traits (Witcombe et al., 1996) leading to low variety adoption rate (Fukuda \& Saad, 2001). The initial stage of PPB involves identification of the end-users preferences and production environments. To achieve this, participatory rural appraisal (PRA) can be employed (Witcombe et al., 2005). During the PRA, the breeder is able to identify and understand both the target environment and farmers. It creates a conducive environment where farmers and breeders exchange ideas and start working towards a common goal (Fukuda \& Saad, 2001).

Against this background, a study was undertaken with the following objectives: to document farmers' practices, key marketing and potato production constraints and determine farmers' potato cultivar preferences, the prevalence of bacterial wilt in the major potato growing areas and establish farmers' management of bacterial wilt.

\section{Materials and Methods}

\subsection{Survey Sites and Descriptions}

A survey was carried out in three major potato producing counties in Kenya namely, Meru, Bomet, and Nakuru between November 2011 and March 2012. These counties were selected because farmers rank potatoes as their most important commercial crop (Kaguongo et al., 2010). In addition, Nakuru and Meru are among the five leading potato producing counties in Kenya (Ng'ang'a et al., 2003). Bomet county was chosen because its potatoes have a unique demand for processing into chips. Bomet and Nakuru are located northwest of Nairobi while Meru is northeast of Nairobi (Figure 1). In each county, sampling was done at several administrative levels: one district was selected per county, two divisions in each district were selected and all wards (in each division) where potato is a major crop were selected. In Meru County, Meru Central district was selected while in Bomet County, Bomet district was selected. Molo district was selected from Nakuru County.

Bomet district is located in the Rift Valley Province. It has two divisions i.e. Bomet Central and Longisa. The district is home to the Kipsigis subgroup of the Kalenjin community. It is about $300 \mathrm{~km}$ northwest of Nairobi and has intensively cultivated steep slopes. The area has a mean monthly temperature of $18^{\circ} \mathrm{C}$ with an annual rainfall ranging between $1100 \mathrm{~mm}$ and $1500 \mathrm{~mm}$ (Jaetzold et al., 2006a). 
Meru Central district is located in Eastern province and represents potato growing areas in the Mt Kenya region. The district is the ancestral home to the Meru community. The district lies to the east of Mt Kenya whose peak cuts through the southwest border of the district. In the district, potatoes are mainly produced in the Kibirichia and Abothuguchi West divisions located on the northern slopes of Mt Kenya. These divisions are characterized by annual precipitation ranging between 1400 and $2600 \mathrm{~mm}$ and monthly temperature averaging $18^{\circ} \mathrm{C}$ (Jaetzold et al., 2006b)

Molo district is located in the Rift Valley province. It comprises two divisions; Molo and Elburgon. Molo is a cosmopolitan district with most of the inhabitants being immigrants from Central and Nyanza provinces. The main inhabitants are Kikuyu, Kalenjin and Kisii communities. The main economic activities are crop production, dairy and sheep keeping. The main cash crops are pyrethrum, potatoes, barley and maize (Jaetzold et al., 2006a).

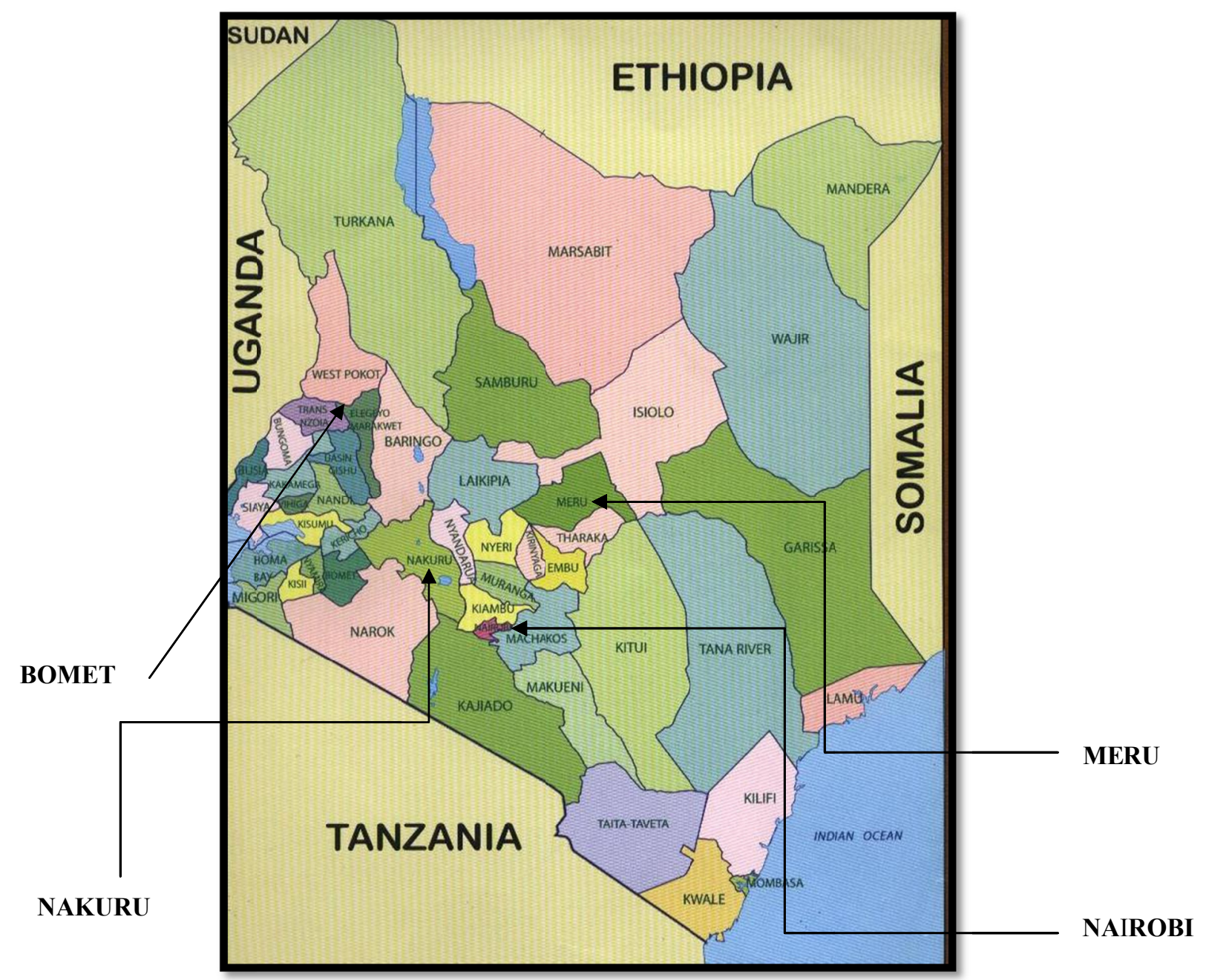

Figure 1. Administrative map of Kenya showing three potato producing counties which were surveyed

\subsection{Sampling Method, Data Collection and Analysis}

Primary data were collected by administering a semi-structured questionnaire to individual farmers. The questionnaire contained open-ended questions that allowed the respondents to express themselves fully in order to gain as much information as possible. After developing the questionnaire, planning meetings were held with the respective district agricultural officers to agree on the areas to be surveyed and the survey routes to be followed in each district. Following these discussions, the survey routes were mapped and the questionnaire pre-tested on ten households in each district. After pre-testing, changes were effected on the questionnaire and the formal survey commenced. 
The survey team consisted of the breeder, a social scientist (both from KARI-Tigoni), an agricultural extension officer and three enumerators (selected from each district). Sampling of the households was both purposeful and systematic; one household (with a current potato crop in the field) within $3 \mathrm{~km}$ intervals along selected routes/paths was selected. If no household had a potato crop in the field within the $3 \mathrm{~km}$ interval, the next potato farm was sampled.

Interviews were carried out in the field using the questionnaire to capture data on farm size, area under potatoes, potato farming history, cropping system, bacterial wilt management and potato cultivar preferences. The interview was conducted in the local language whenever possible; otherwise it was conducted in Kiswahili, the national language.

The survey team visited the potato plot and scored for bacterial wilt incidence. The incidence was established by measuring the percentage of wilting plants. Prevalence of bacterial wilt was calculated as the number of farms affected by the disease expressed as a percentage of all farms visited in an area.

A global positioning system (GPS-Garmin Inc. Kansas, USA) was used for geo-referencing purposes to supply coordinates (latitudes, longitudes, altitudes) for specific locations. The primary data was analysed using SPSS for Windows Release Version 18.0 (SPSS Inc., 2009). Data analysis was descriptive (means and percentages).

\section{Results}

\subsection{Farmers and Farm Characteristics}

A total of 253 farmers were interviewed. In each district, over $60 \%$ of the farmers interviewed were men (Table 1). The farms are located between 1933 and 2723 meters above sea level (masl).

Table 1. Descriptions of the three potato growing districts surveyed in Kenya

\begin{tabular}{llllll}
\hline County & District & Divisions & Altitude (masl) & No of farmers interviewed & \% Male farmers \\
\hline \multirow{2}{*}{ Meru } & \multirow{2}{*}{ Meru Central } & Abothuguchi west & 2126 & 52 & 61.8 \\
& & Kibirichia & 2130 & 41 & 70.7 \\
\multirow{2}{*}{ Bomet } & \multirow{2}{*}{ Bomet } & Longisa & 1933 & 37 & 70.3 \\
& & Bomet Central & 2279 & 42 & 88.1 \\
\multirow{2}{*}{ Nakuru } & \multirow{2}{*}{ Molo } & Elburgon & 2723 & 58 & 65.5 \\
& & Molo & 2542 & 23 & 69.6 \\
\hline Total & & & 253 & \\
\hline
\end{tabular}

Masl= Meters above sea level.

The area surveyed ranged from upper midlands (below 2000 masl) to upper highlands (over 2700 masl) (Table 2). Molo and Elburgon represent the upper highlands while the other divisions represent the upper midlands and lower highlands.

Table 2. Agro-ecological zones of the six potato growing divisions in Kenya surveyed (\% of respondents)

\begin{tabular}{cccccccc}
\hline Agro-ecological zone & Altitude (masl) & Bomet Central & Longisa & Abothuguchi West & Kibirichia & Elburgon & Molo \\
\hline Upper Midlands & less than 2000 & 0.0 & 2.7 & 59.6 & 0.0 & 0.0 & 0.0 \\
Lower Highlands & $2001-2400$ & 100.0 & 97.3 & 40.4 & 95.1 & 0.0 & 0.0 \\
Upper Highlands & $2401-2700$ & 0.0 & 0.0 & 0.0 & 4.9 & 50.0 & 100.0 \\
Upper Highlands & above 2701 & 0.0 & 0.0 & 0.0 & 0.0 & 50.0 & 0.0 \\
\hline
\end{tabular}

In all districts potatoes have been grown for more than nine years. In Meru Central district farmers have been growing potatoes for a longer period than in the other two districts (Table 3). The short potato farming history in Molo district could be attributed to the fact that most farmers are immigrants from other areas, mostly members of Kikuyu community. The recent introduction of potato growing in Bomet district could have been related to the establishment of a company which contracts farmers in this area to plant Dutch Robyjn for processing into chips 
and french fries. Bomet district is mainly a tea growing area where the good potato prices in recent years have lured farmers into potato farming.

The average farm sizes range from 0.9 to 2.1 hectares (Table 3). This confirms the general observation that most potatoes in Kenya are predominantly grown by small-scale farmers; the mean farm size are about 2 hectares while potato plots are about 0.5 hectares (Kabira, 1983). These potato growing areas are densely populated and hence the small farm sizes.

A positive correlation $(r=0.66)$ was observed between farm sizes and the area under potatoes. This means that farmers with bigger farms allocate bigger plots to potatoes. Wakahiu et al. (2007) found a correlation $(r=0.260)$ between farm sizes and the area under potatoes in a previous study.

Table 3. Average farm size, area under potatoes, years of potato production in three districts in Kenya

\begin{tabular}{|c|c|c|c|c|}
\hline District & Divisions & $\begin{array}{l}\text { Ave. Farm size } \\
\text { (hectares) }\end{array}$ & $\begin{array}{l}\text { Ave. Area under potatoes } \\
\text { hectares } \\
\text { (\% of total farm size) }\end{array}$ & $\begin{array}{l}\text { Ave. years of potato } \\
\text { growing }\end{array}$ \\
\hline \multirow{2}{*}{ Bomet } & Bomet Central & 1.70 & $0.49(28.8)$ & 9.5 \\
\hline & Longisa & 1.66 & $0.45(25.5)$ & 9.3 \\
\hline \multirow[t]{2}{*}{ Meru Central } & $\begin{array}{l}\text { Abothuguchi } \\
\text { West }\end{array}$ & 0.97 & $0.28(29.0)$ & 16.0 \\
\hline & Kibirichia & 1.17 & $0.49(41.5)$ & 23.3 \\
\hline \multirow{2}{*}{ Molo } & Elburgon & 1.98 & $0.89(45.7)$ & 9.6 \\
\hline & Molo & 2.10 & $1.13(47.9)$ & 9.2 \\
\hline
\end{tabular}

Most potatoes are grown as pure stands in small scale intensive farming systems. Few farmers (5.5\%) intercrop potatoes with crops such as maize or beans. The rest grow potatoes in pure stands and practice crop rotation (Table 4). Occasionally, in cases where farm size is very small, potatoes are grown without rotation. In Molo division, about $30 \%$ of the farmers surveyed do not practice crop rotation (Table 4 ).

Table 4. Common rotational sequences ( $\%$ of respondents) of potato production in three districts in Kenya

\begin{tabular}{lllllll}
\hline \multirow{2}{*}{ Rotation sequence } & \multicolumn{2}{l}{ District and divisions } & & & \\
\cline { 2 - 6 } & \multicolumn{2}{l}{ Bomet } & & Meru Central & & \multicolumn{2}{l}{ Molo } \\
\cline { 2 - 6 } & Bomet Central & Longisa & Abothuguchi West & Kibirichia & Elburgon & Molo \\
\hline potato, maize, potato & 14.3 & 2.7 & 1.9 & 12.2 & 34.5 & 8.7 \\
potato, maize+beans, potato & 50.0 & 37.8 & 25.0 & 0.0 & 17.2 & 34.8 \\
potato, maize+bean/cabbage,potato & 23.8 & 40.5 & 13.5 & 0.0 & 0.0 & 0.0 \\
potato, maize/cabbage,potato & 0.0 & 0.0 & 17.3 & 9.8 & 17.2 & 17.4 \\
potato, cabbage, potato & 0.0 & 0.0 & 5.8 & 9.8 & 5.2 & 4.3 \\
potato, maize/wheat, potato & 0.0 & 0.0 & 0.0 & 14.6 & 1.7 & 0.0 \\
potato, maize+bean/wheat, potato & 0.0 & 0.0 & 0.0 & 7.3 & 0.0 & 0.0 \\
others & 9.5 & 16.2 & 15.4 & 26.8 & 0.0 & 8.7 \\
\hline No rotation & 2.4 & 2.7 & 19.2 & 7.3 & 15.5 & 30.4 \\
\hline
\end{tabular}

Maize + beans $=$ maize intercropped with beans; maize + beans/cabbage $=$ maize intercropped with beans or cabbage alone; potato, maize, potato $=$ potatoes followed by maize then potatoes in that sequence; maize/cabbage $=$ maize or cabbage. 
Other rotational sequences observed involve minor crops such as carrots, snow peas, millets etc. Over $99 \%$ of farmers plant a range of crops on their small farms mainly to cushion themselves against the risk of crop failure (Table 5). Wheat production is specific to Kibirichia while tea is specific to Bomet Central.

Table 5. Crops commonly grown by farmers (\% of respondents) in three districts in Kenya

\begin{tabular}{|c|c|c|c|c|c|c|}
\hline \multirow{3}{*}{ Crops } & \multicolumn{6}{|c|}{ Districts and Divisions } \\
\hline & \multicolumn{2}{|l|}{ Bomet } & \multicolumn{2}{|l|}{ Meru Central } & \multicolumn{2}{|l|}{ Molo } \\
\hline & $\begin{array}{l}\text { Bomet } \\
\text { Central }\end{array}$ & Longisa & $\begin{array}{l}\text { Abothuguchi } \\
\text { West }\end{array}$ & Kibirichia & Elburgon & Molo \\
\hline Maize & 97.6 & 89.2 & 92.3 & 75.6 & 91.4 & 82.6 \\
\hline beans & 76.2 & 91.9 & 76.9 & 34.1 & 44.8 & 56.5 \\
\hline potatoes & 100.0 & 100.0 & 100.0 & 100.0 & 100.0 & 100.0 \\
\hline cabbage & 31.0 & 54.1 & 61.5 & 56.1 & 46.6 & 39.1 \\
\hline Tea & 47.6 & 0.0 & 15.4 & 0.0 & 0.0 & 0.0 \\
\hline Coffee & 0.0 & 0.0 & 9.6 & 0.0 & 0.0 & 0.0 \\
\hline wheat & 0.0 & 0.0 & 0.0 & 41.5 & 3.4 & 0.0 \\
\hline bananas & 0.0 & 0.0 & 11.5 & 0.0 & 0.0 & 0.0 \\
\hline
\end{tabular}

\subsection{Potato Farming System}

About $90 \%$ of all the farmers interviewed produce potatoes both for cash and food (Figure 2). This possibly explains the allocation of potatoes to large portions of their farms. Ng'ang'a et al. (2003) found that farmers in Nyandarua, Meru Central, Bomet, Nakuru, Nyeri and Keiyo districts grow potatoes mainly for cash, selling over $60 \%$ of their produce.

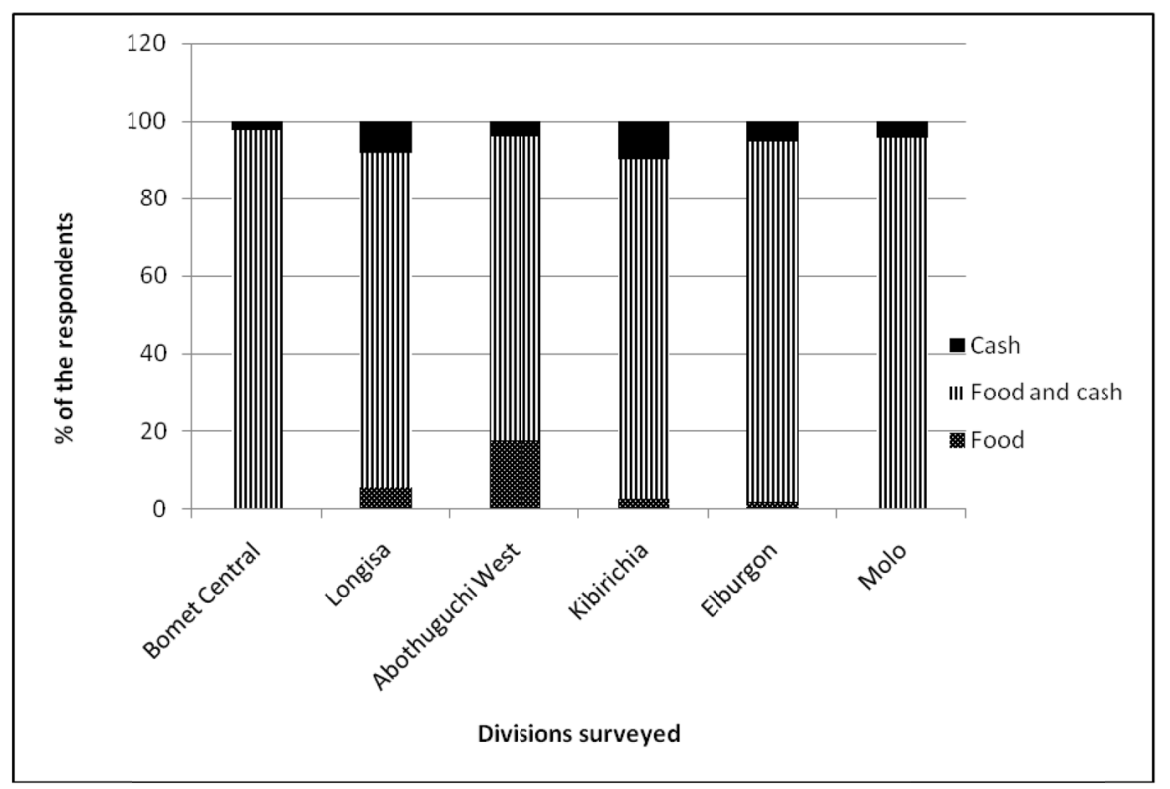

Figure 2. Proportion (\%) of farmers that grow potatoes for cash, cash and food, or food in six divisions in Kenya

Farmers generally obtain seed tubers from informal sources (Table 6). The formal seed sources (ADC and KARI Tigoni) are utilized in Bomet district, and to a lesser extent, Elburgon division. The majority of farmers from Abothuguchi West obtain their seeds from the neighbouring Kibirichia division. They argue that potatoes from Kibirichia are rainfed and hence have a lower chance of having bacterial wilt. Farmers from Abothuguchi West believe that seed from their local area had bacterial wilt because it is mainly grown under irrigation. 
Table 6. Percentage of farmers obtaining potato seeds from different sources in six divisions in Kenya.

\begin{tabular}{lcccccc}
\hline Seed source & Bomet Central & Longisa & Elburgon & Molo & $\begin{array}{c}\text { Abothuguchu } \\
\text { West }\end{array}$ & Kibirichia \\
\hline ADC & 4.8 & 2.7 & 0.0 & 0.0 & 0.0 & 0.0 \\
ADC, neighbours & 2.4 & 0.0 & 6.9 & 0.0 & 0.0 & 0.0 \\
KARI Tigoni, own & 2.4 & 8.1 & 0.0 & 0.0 & 0.0 & 0.0 \\
neighbours & 38.1 & 43.2 & 34.5 & 78.3 & 1.9 & 9.8 \\
Own (farm-saved) & 33.3 & 21.6 & 50 & 17.4 & 3.8 & 90.2 \\
own, neighbours & 19 & 16.2 & 5.2 & 4.3 & 1.9 & 0.0 \\
KARI Tigoni & 0.0 & 8.1 & 0.0 & 0.0 & 1.9 & 0.0 \\
Local market & 0.0 & 0.0 & 1.7 & 0.0 & 9.6 & 0.0 \\
ADC,KARI Tigoni & 0.0 & 0.0 & 1.7 & 0.0 & 0.0 & 0.0 \\
Farmers (Kibirichia) & 0.0 & 0.0 & 0.0 & 0.0 & 76.9 & 0.0 \\
market, own & 0.0 & 0.0 & 0.0 & 0.0 & 3.8 & 0.0 \\
\hline
\end{tabular}

ADC= Agricultural Development Corporation

KARI= Kenya Agricultural Research Institute

All farmers sampled from Bomet Central and Longisa divisions grow red-skinned potatoes (Figure 3). Farmers from Elburgon and Molo divisions grow mainly the white-skinned varieties. Most farmers in Kibirichia and Abothuguchi West grow the red-skinned varieties.

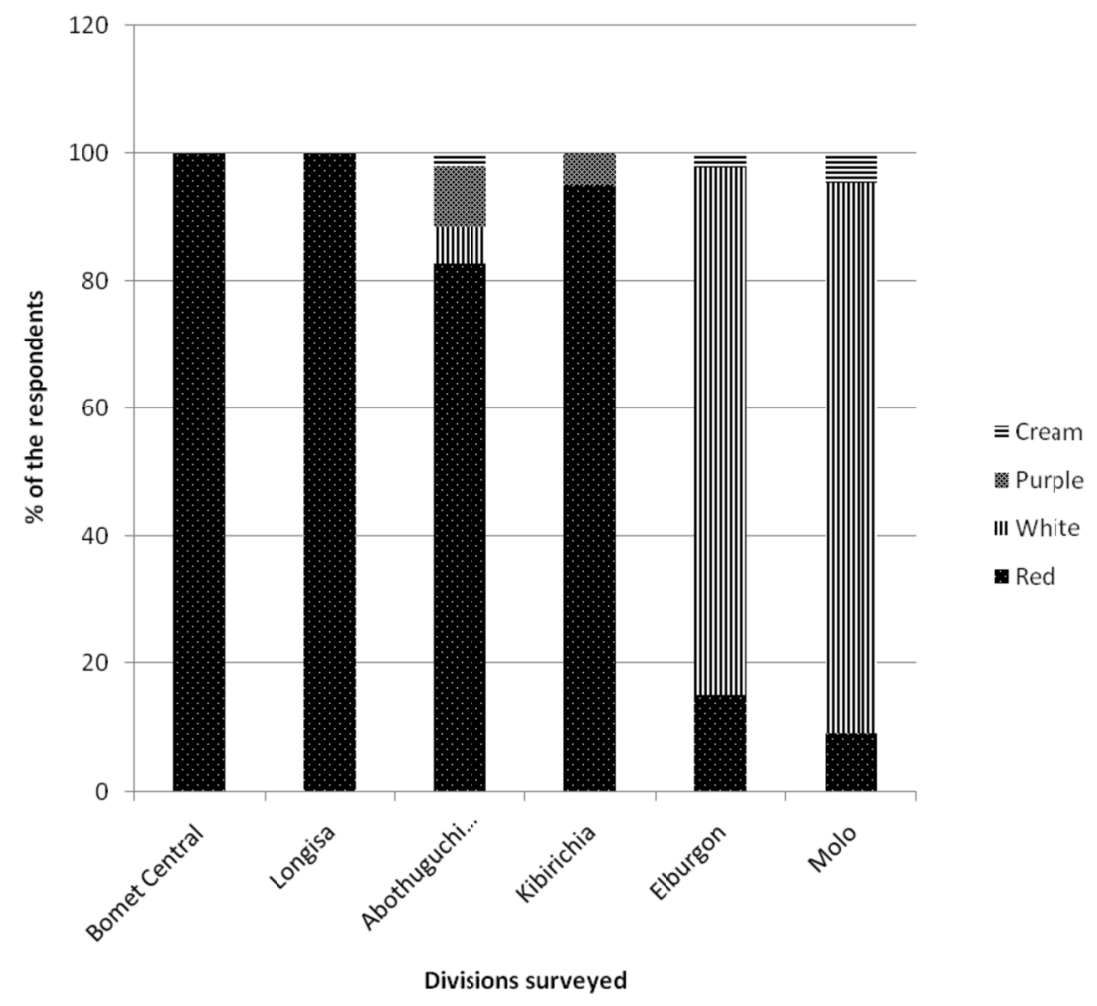

Figure 3. Skin colour of the potato cultivars grown by farmers in six divisions in Kenya

Most farmers across the districts grow white-fleshed potatoes (Figure 4). 


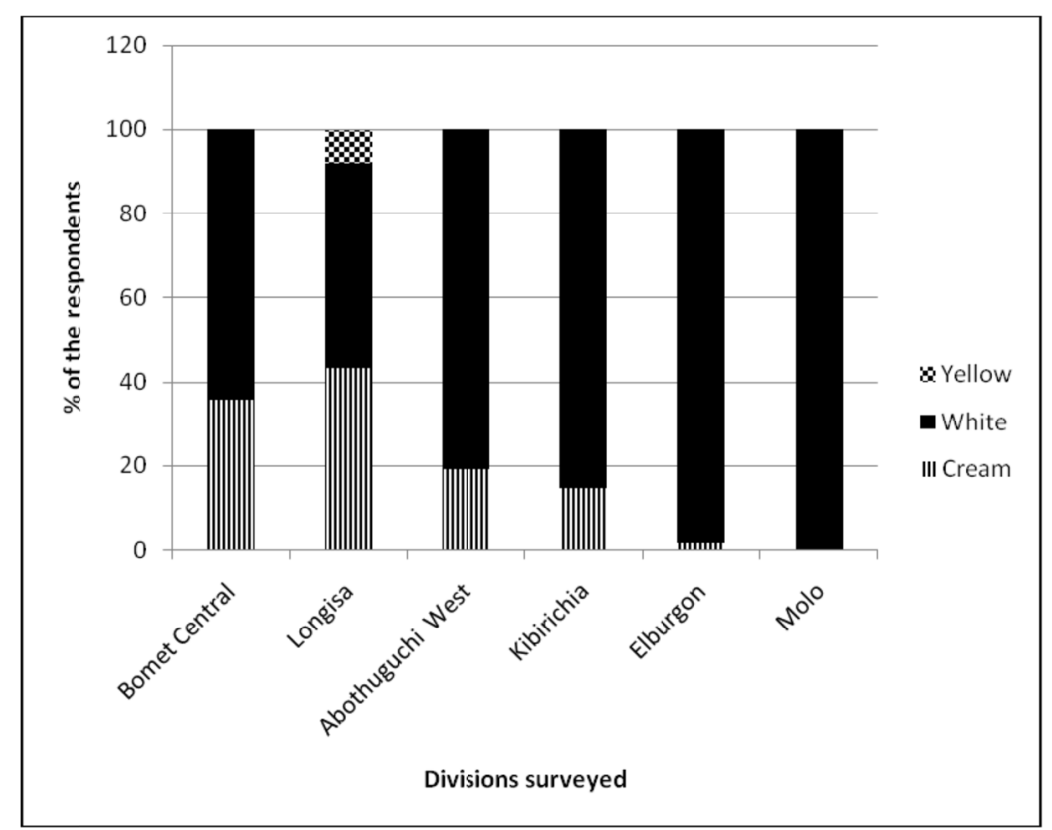

Figure 4. Flesh colour of the potato cultivars grown by farmers in six divisions in Kenya

All farmers in Bomet Central and almost all farmers in Longisa divisions grow the red-skinned Dutch Robyjn (Table 7). Their next popular variety is the red-skinned Desiree. In both Abothuguchi West and Kibirichia, the red-skinned Asante is grown by a majority of farmers followed by the white-skinned Tigoni. The white-skinned Cangi is the most popular in Elburgon and Molo divisions followed by the white-skinned Tigoni.

Table 7. Potato cultivars grown by farmers in six divisions in Kenya ( $\%$ of the respondents)

\begin{tabular}{lllllll}
\hline Potato Cultivar & Bomet Central & Longisa & Abothuguchi West & Kibirichia & Elburgon & Molo \\
\hline Dutch & 100.0 & 97.3 & 0.0 & 0.0 & 0.0 & 0.0 \\
Desiree & 26.2 & 16.2 & 0.0 & 0.0 & 1.7 & 0.0 \\
asante & 2.4 & 2.7 & 88.5 & 82.9 & 10.3 & 0.0 \\
Tigoni & 9.5 & 5.4 & 59.6 & 41.5 & 44.8 & 26.1 \\
Kenya Karibu & 2.4 & 2.7 & 0.0 & 0.0 & 8.6 & 17.4 \\
Cangi & 0.0 & 2.7 & 0.0 & 2.4 & 96.6 & 100.0 \\
ngure & 0.0 & 0.0 & 7.7 & 2.4 & 0.0 & 0.0 \\
Kerr's pink & 0.0 & 0.0 & 7.7 & 2.4 & 0.0 & 0.0 \\
Kibururu & 0.0 & 0.0 & 7.7 & 29.3 & 0.0 & 0.0 \\
Kombiro & 0.0 & 0.0 & 1.9 & 4.9 & 0.0 & 0.0 \\
Arka & 0.0 & 0.0 & 1.9 & 2.4 & 0.0 & 0.0 \\
Komesha & 0.0 & 0.0 & 0.0 & 2.4 & 10.3 & 17.4 \\
Nyayo & 0.0 & 0.0 & 0.0 & 0.0 & 13.8 & 8.7 \\
Thimathuti & 0.0 & 0.0 & 0.0 & 0.0 & 3.4 & 4.3 \\
\hline
\end{tabular}

Market access is the most important factor considered by farmers in Bomet Central and Longisa divisions in deciding which potato cultivar to grow (Table 8). In all the other areas, high yield was the most important factor considered in the cultivar choice. Early maturity was considered an important factor by farmers from Elburgon and Molo divisions as it allows for more crop cycles per year. Early maturity and high yields are the main qualities that have made the local landrace Cangi very popular in these two divisions. 
Table 8 . Reasons given by potato farmers in deciding the potato cultivar to plant in six divisions in Kenya (\% of respondents)

\begin{tabular}{lcccccc}
\hline Reasons & $\begin{array}{c}\text { Bomet } \\
\text { Central }\end{array}$ & Longisa & $\begin{array}{c}\text { Abothuguchi } \\
\text { West }\end{array}$ & Kibirichia & Elburgon & Molo \\
\hline Drought tolerant & 3.8 & 3.1 & 0.0 & 6.6 & 5.6 & 0.0 \\
Available market & 44.3 & 54.7 & 1.4 & 8.2 & 27 & 32.7 \\
High yielding & 17.7 & 7.8 & 59.5 & 63.9 & 31 & 32.7 \\
Good taste & 15.2 & 34.4 & 13.5 & 1.6 & 4.0 & 8.2 \\
Resists late blight & 15.2 & 0.0 & 6.8 & 13.1 & 5.6 & 4.1 \\
Only available variety & 3.8 & 0.0 & 0.0 & 3.3 & 0.8 & 2.0 \\
Matures early & 0.0 & 0.0 & 14.9 & 3.3 & 25.4 & 20.4 \\
Long post-harvest storage & 0.0 & 0.0 & 4.1 & 0.0 & 0.8 & 0.0 \\
\hline
\end{tabular}

Generally, there was a high turnover of potato cultivars over the past five years (Table 9). About $34.5 \%$ farmers from Bomet Central and 32\% from Longisa did not change their favourite potato culyivar. Most farmers in Meru Central district abandoned the red-skinned Kerr's Pink and Ngure cultivars. Farmers from Molo district abandoned the white- skinned Nyayo cultivar.

Table 9. Potato cultivars abandoned by farmers over the past five years in six divisions in Kenya (\% of respondents)

\begin{tabular}{lcccccc}
\hline Abandoned varieties & $\begin{array}{c}\text { Bomet } \\
\text { Central }\end{array}$ & Longisa & $\begin{array}{c}\text { Abothuguchi } \\
\text { West }\end{array}$ & Kibirichia & Elburgon & Molo \\
\hline Annett & 6.9 & 0.0 & 0.0 & 0.0 & 0.0 & 0.0 \\
R.Eburu & 8.6 & 0.0 & 0.0 & 1.1 & 0.0 & 0.0 \\
Tigoni & 13.8 & 10.0 & 0.0 & 1.1 & 4.9 & 4.9 \\
Desiree & 8.6 & 20.0 & 5.3 & 3.4 & 13.2 & 14.6 \\
Nyayo & 3.4 & 4.0 & 6.3 & 2.3 & 24.3 & 22.0 \\
Asante & 1.7 & 2.0 & 1.1 & 1.1 & 2.1 & 0.0 \\
Meru & 10.3 & 0.0 & 0.0 & 3.4 & 3.5 & 4.9 \\
K. Karibu & 1.7 & 0.0 & 0.0 & 0.0 & 2.1 & 2.4 \\
Arka & 3.4 & 0.0 & 1.1 & 0.0 & 0.0 & 0.0 \\
Kibururu & 3.4 & 4.0 & 6.3 & 8.0 & 0.7 & 0.0 \\
Cardinal & 1.7 & 0.0 & 0.0 & 0.0 & 0.0 & 0.0 \\
Kanongo & 1.7 & 2.0 & 0.0 & 0.0 & 0.7 & 0.0 \\
Othorongongo & 0.0 & 4.0 & 0.0 & 0.0 & 0.0 & 0.0 \\
rangimbili & 0.0 & 12.0 & 0.0 & 0.0 & 0.0 & 0.0 \\
Kienyenji & 0.0 & 8.0 & 0.0 & 0.0 & 0.0 & 0.0 \\
pmpernel & 0.0 & 2.0 & 0.0 & 0.0 & 0.0 & 0.0 \\
Kerr's pink & 0.0 & 0.0 & 31.6 & 28.7 & 0.0 & 0.0 \\
Roslin Tana & 0.0 & 0.0 & 4.2 & 0.0 & 2.1 & 2.4 \\
Ngure & 0.0 & 0.0 & 24.2 & 33.3 & 0.0 & 0.0 \\
Dutch & 0.0 & 0.0 & 3.2 & 0.0 & 17.4 & 12.2 \\
Munyiri & 0.0 & 0.0 & 4.2 & 0.0 & 0.0 & 0.0 \\
Komesha & 0.0 & 0.0 & 1.1 & 2.3 & 0.7 & 2.4 \\
Munyonge & 0.0 & 0.0 & 1.1 & 0.0 & 0.0 & 0.0 \\
Ntuka & 0.0 & 0.0 & 1.1 & 0.0 & 0.0 & 0.0 \\
Kombiro & 0.0 & 0.0 & 0.0 & 3.4 & 0.0 & 0.0 \\
Romano & 0.0 & 0.0 & 0.0 & 3.4 & 0.0 & 0.0 \\
Thimathuti & 0.0 & 0.0 & 0.0 & 1.1 & 4.2 & 2.4 \\
Karchi & 0.0 & 0.0 & 0.0 & 2.3 & 0.0 & 0.0 \\
Kiora & 0.0 & 0.0 & 0.0 & 1.1 & 0.0 & 0.0 \\
Ninty nine & 0.0 & 0.0 & 0.0 & 1.1 & 0.0 & 0.0 \\
Kihoro & 0.0 & 0.0 & 0.0 & 0.0 & 10.4 & 14.6 \\
Karoraiguru & 0.0 & 0.0 & 0.0 & 0.0 & 1.4 & 0.0 \\
Susana & 0.0 & 0.0 & 0.0 & 0.0 & 1.4 & 0.0 \\
Nderaciana & 0.0 & 0.0 & 0.0 & 0.0 & 0.7 & 0.0 \\
mwezimoja & 0.0 & 0.0 & 0.0 & 0.0 & 0.7 & 0.0 \\
Baraka & 0.0 & 0.0 & 0.0 & 0.0 & 2.4 \\
\hline None & 32.0 & 9.5 & 2.3 & 9.7 & 14.6 \\
\hline & & & & & & \\
\hline
\end{tabular}


Farmers who changed their popular potato cultivar in Bomet district mainly did so due to lack of market for the cultivars they had been growing (Table 10). Low yield was the main reason behind farmers in Meru Central and Molo districts rejecting some potato cultivars.

Table 10. Reasons given by farmers in six divisions in Kenya for rejecting some potato cultivars five years ago (\% of respondents)

\begin{tabular}{lllllll}
\hline Reasons for rejection & Bomet Central & Longisa & $\begin{array}{l}\text { Abothuguchi } \\
\text { West }\end{array}$ & Kibirichia & Elburgon & Molo \\
\hline Lack of market & 45.2 & 40.5 & 0.0 & 5.5 & 28.9 & 44.4 \\
Low yield & 4.8 & 7.1 & 57.9 & 63.6 & 40.8 & 33.3 \\
Susceptibility to late blight & 2.4 & 0.0 & 14.0 & 27.3 & 3.9 & 0.0 \\
Bad taste & 0.0 & 9.5 & 0.0 & 0.0 & 0.0 & 0.0 \\
Late maturity & 0.0 & 2.4 & 3.5 & 0.0 & 7.9 & 0.0 \\
Lack of seeds & 0.0 & 2.4 & 7.0 & 0.0 & 0.0 & 0.0 \\
Poor post-harvest storage & 0.0 & 0.0 & 1.8 & 0.0 & 0.0 & 0.0 \\
\hline none & 47.6 & 38.1 & 15.8 & 3.6 & 18.4 & 22.2 \\
\hline
\end{tabular}

\subsection{Major Potato Marketing Constraints}

In all divisions surveyed, produce price fluctuation is the major marketing constraint (Table 11).

Table 11. Major marketing constraints encountered by potato farmers in six divisions in Kenya (\% of respondents)

\begin{tabular}{lllllll}
\hline Marketing constraint & $\begin{array}{l}\text { Bomet } \\
\text { Central }\end{array}$ & Longisa & Abothuguchi West & Kibirichia & Elburgon & Molo \\
\hline Price fluctuations & 45.2 & 40.5 & 19.2 & 17.1 & 41.4 & 17.4 \\
Poor roads & 33.3 & 13.5 & 0.0 & 12.2 & 8.6 & 21.7 \\
Brokers & 11.9 & 5.4 & 0.0 & 0.0 & 12.1 & 13.0 \\
Extended bag & 2.4 & 21.6 & 7.7 & 9.8 & 36.2 & 26.1 \\
Lack of market & 0.0 & 0.0 & 15.4 & 2.4 & 0.0 & 0.0 \\
\hline None & 31.0 & 37.8 & 63.5 & 70.7 & 44.8 & 47.8 \\
\hline
\end{tabular}

Farmers pack their potatoes in extended bags Figure 5. Traders buy potatoes on per bag basis and not on weight basis. On the market, however, the traders sell the potatoes in smaller containers such as normal sized bags or buckets. Therefore, an extended bag is advantageous to the trader but exploitative to the farmers. 

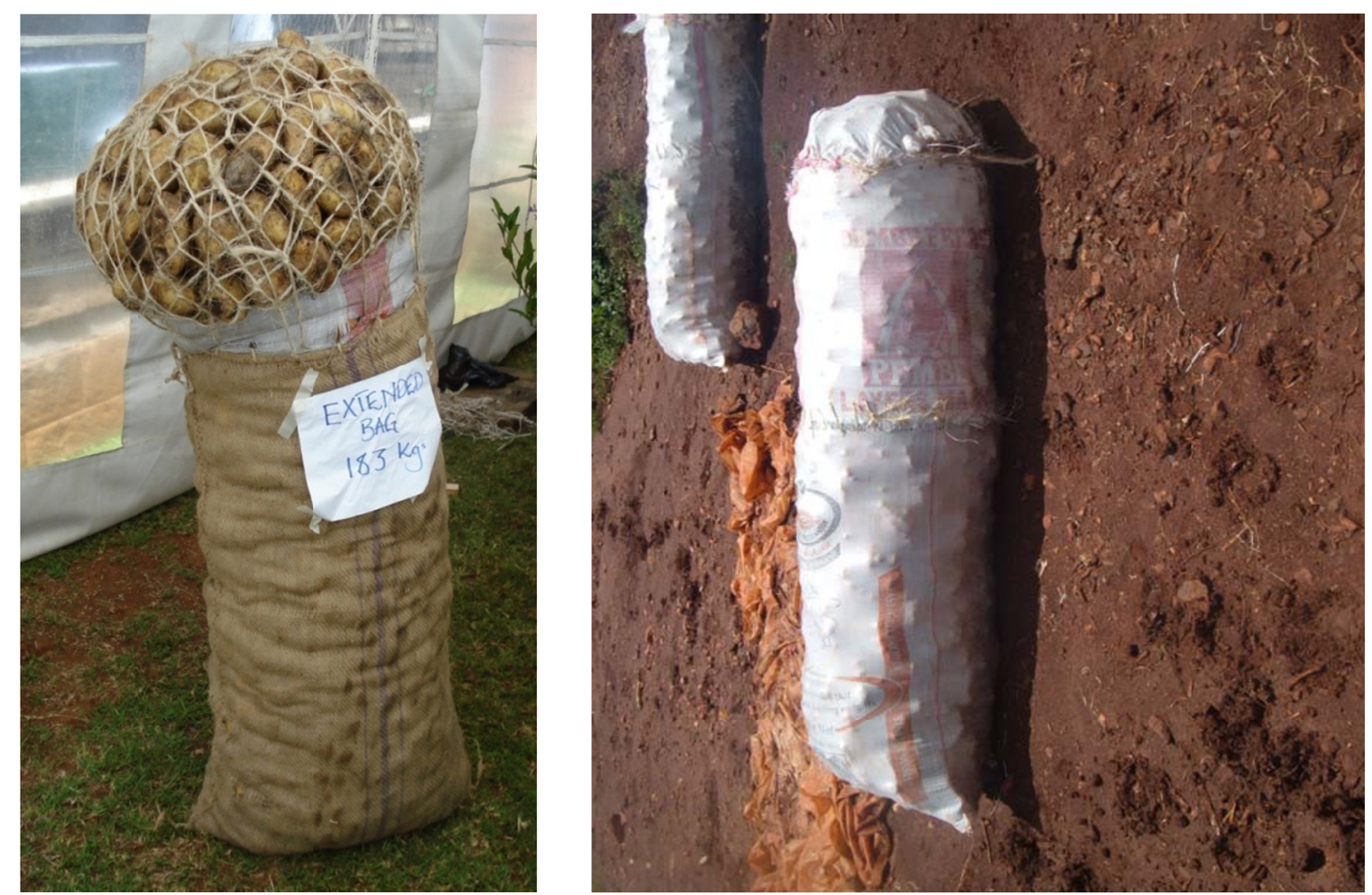

Figure 5. Extended potato bags used to pack potatoes in Kenya

\subsection{Potato Production Constraints}

Over $75 \%$ of the farmers in the surveyed divisions cited diseases as the main potato production constraint (Table 12). The high cost of fungicides and fertilizer was also mentioned as an important constraint. Lack of clean seeds and high seed costs were cited as production constraints by some farmers.

Table 12. Potato production constraints as cited by farmers in six divisions in Kenya (\% of respondents)

\begin{tabular}{lllllll}
\hline & Bomet & \multicolumn{5}{c}{ Abothuguchi } \\
Production Constraint & Central & Longisa & West & Kibirichia & Elburgon & Molo \\
\hline Diseases & 92.9 & 100 & 96.2 & 75.6 & 98.3 & 91.3 \\
Unpredictable rainfall & 26.2 & 29.7 & 0.0 & 9.8 & 22.4 & 4.3 \\
High fungicide costs & 9.5 & 8.1 & 0.0 & 0.0 & 10.3 & 21.7 \\
High fertilizer costs & 16.7 & 21.6 & 34.6 & 51.2 & 27.6 & 21.7 \\
Lack of clean seeds & 11.9 & 27 & 5.8 & 0.0 & 8.6 & 8.7 \\
Insect pests & 2.4 & 2.7 & 7.7 & 24.4 & 5.2 & 4.3 \\
High seed costs & 0.0 & 2.7 & 19.2 & 12.2 & 1.7 & 0.0 \\
\hline
\end{tabular}

Among the diseases, bacterial wilt is the most common in all divisions surveyed followed by late blight (Table 13). These findings are in agreement with previous studies by Kaguongo et al. (2010) who found that bacterial wilt is common in all potato growing areas of Kenya affecting $77 \%$ of potato farms followed by late blight (67\%), and viral diseases (12\%). Despite $90 \%$ of farmers from Kibirichia using their own seed (Table 6), bacterial wilt prevalence is somehow lower than the other areas. This is possibly because they have been educated on selection of clean seed from their own fields and general field hygiene. 
Table 13. Major diseases affecting potato production in six divisions in Kenya ( $\%$ of respondents)

\begin{tabular}{lcccccc}
\hline Disease & $\begin{array}{c}\text { Bomet } \\
\text { Central }\end{array}$ & Longisa & $\begin{array}{c}\text { Abothuguchi } \\
\text { West }\end{array}$ & Kibirichia & Elburgon & Molo \\
\hline *Bacterial wilt & 90.5 & 75.7 & 100.0 & 61.0 & 98.3 & 100.0 \\
Late blight & 76.2 & 70.3 & 75.0 & 56.1 & 46.6 & 52.2 \\
Leaf rust & 2.4 & 0.0 & 0.0 & 0.0 & 0.0 & 0.0 \\
viruses & 0.0 & 24.3 & 38.5 & 24.4 & 10.3 & 34.8 \\
leafminer & 0.0 & 0.0 & 5.8 & 0.0 & 0.0 & 0.0 \\
nematodes & 0.0 & 0.0 & 0.0 & 2.4 & 0.0 & 0.0 \\
\hline None & 0.0 & 0.0 & 0.0 & 19.5 & 1.7 & 0.0 \\
\hline
\end{tabular}

* = was directly observed in the fields. The other diseases were reported by the farmers during interview.

About $40 \%$ of all the farms visited in Kibirichia did not have bacterial wilt (Table 14). Most farms across all divisions had bacterial wilt incidence of $50 \%$ and below.

Table 14. Bacterial wilt incidence (\%) in six divisions in Kenya (\% of farms visited)

\begin{tabular}{lcccccc}
\hline Bacterial wilt incidence (\%) & Bomet Central & Longisa & Abothuguchi West & Kibirichia & Elburgon & Molo \\
\hline 0 & 9.5 & 24.3 & 0.0 & 39.0 & 1.7 & 0.0 \\
$1-10$ & 14.3 & 10.8 & 3.8 & 41.5 & 1.7 & 8.7 \\
$11-20$ & 19.0 & 8.1 & 19.2 & 12.2 & 12 & 0.0 \\
$21-30$ & 9.6 & 51.3 & 32.7 & 2.4 & 1.7 & 13 \\
$31-40$ & 7.2 & 5.4 & 32.7 & 0.0 & 82.6 & 56.3 \\
$41-50$ & 40.5 & 0.0 & 3.8 & 2.4 & 0.0 & 21.7 \\
$51-60$ & 0.0 & 0.0 & 1.9 & 0.0 & 0.0 & 0.0 \\
$61-70$ & 0.0 & 0.0 & 1.9 & 2.4 & 0.0 & 0.0 \\
$71-80$ & 0.0 & 0.0 & 0.0 & 0.0 & 0.0 & 0.0 \\
$81-90$ & 0.0 & 0.0 & 0.0 & 0.0 & 0.0 & 0.0 \\
$90-100$ & 0.0 & 0.0 & 3.8 & 0.0 & 0.0 & 0.0 \\
\hline
\end{tabular}

There was a negative Spearman's Rho correlation $(r=-0.295)$ between bacterial wilt incidence and altitude. This is to be expected because disease expression is favoured by high temperatures. However, this does not mean there are no bacterial diseases; in the cold highlands the real danger is latent infection. A negative correlation $(\mathrm{r}=$ -0.354) between bacterial wilt incidence and altitude has previously been observed (Wakahiu et al., 2007). According to a previous study, the highest disease incidence was recorded in sites located 1800-2000 masl while the lowest incidence was observed in sites located over 2600 metres above sea level (Ateka et al., 2001).

\subsection{Management of Bacterial Wilt}

In addition to crop rotation (Table 4), farmers use different methods in managing the disease in the field (Table 15). About $30 \%$ of the farmers surveyed in Molo division did nothing extra to control the disease (Table 15). 
Table 15. Farmers' management of wilting plants in six divisions in Kenya (\% of respondents)

\begin{tabular}{lcccccc}
\hline $\begin{array}{l}\text { Management of wilting potato } \\
\text { plants }\end{array}$ & $\begin{array}{c}\text { Bomet } \\
\text { Central }\end{array}$ & Longisa & $\begin{array}{c}\text { Abothuguchi } \\
\text { West }\end{array}$ & Kibirichia & Elburgon & Molo \\
\hline None & 21.4 & 21.6 & 11.5 & 12.2 & 19 & 30.4 \\
Spray with fungicides & 2.4 & 0.0 & 0.0 & 0.0 & 1.7 & 0.0 \\
Rogue and throw in a hole & 14.3 & 2.7 & 7.7 & 4.9 & 0.0 & 0.0 \\
Rogue, throw in hole and bury & 4.8 & 13.5 & 17.3 & 29.3 & 8.6 & 8.0 \\
Rogue and throw in a hole and burn, & 16.7 & 35.1 & 28.8 & 4.9 & 15.5 & 0.0 \\
apply ash in the affected area & 4.8 & 5.4 & 5.8 & 4.9 & 6.9 & 13.0 \\
Rogue and leave on the path & 16.7 & 5.4 & 7.7 & 0.0 & 41.4 & 43.5 \\
Rogue and throw far away & 0.0 & 0.0 & 9.6 & 2.4 & 0.0 & 4.3 \\
Rogue and feed cows & 0.0 & 0.0 & 7.7 & 0.0 & 0.0 & 0.0 \\
Rogue and leave on the field & 9.5 & 0.0 & 5.8 & 2.4 & 5.2 & 0.0 \\
Rogue, throw in a hole and burn & 9.5 & 16.2 & 0.0 & 39 & 1.7 & 0.0 \\
N/A & & & & & & \\
\hline
\end{tabular}

Over $15 \%$ of farmers in all divisions except Molo and Kibirichia manage the disease by uprooting and throwing the wilting plants and their tubers in a hole dug outside the field and burning them. They also remove the soil (from where the wilting plant has been uprooted) and throw it in the hole. Subsequently they apply two handfuls of ash in the place where the plant has been uprooted and mix it well with the soil (Table 15). This bacterial wilt management strategy is currently being promoted by KARI. Ashes and lime are known to suppress the bacteria probably by raising the soil $\mathrm{pH}$ (Gildemacher et al., 2007). In addition, ashes have the added advantage of containing nutrients such as potassium and phosphorus. There is no rule on the exact amounts to be applied; one handful of lime or two handfuls of ashes can be used as a maximum dose per plant (Gildemacher et al., 2007).

After harvesting, the majority of the farmers in all the divisions surveyed (except Molo) throw the rotten tubers in a hole and bury (Table 16).

Table 16. Farmers' management of rotten tubers after harvesting potatoes in six divisions in Kenya ( $\%$ of respondents)

\begin{tabular}{lllllll}
\hline Management of rotten tubers & Bomet Central & Longisa & Abothuguchi West & Kibirichia & Elburgon & Molo \\
\hline Throw in a hole & 2.4 & 2.7 & 15.4 & 17.1 & 0 & 8.7 \\
Leave on the path & 7.1 & 8.1 & 1.9 & 0 & 6.9 & 4.3 \\
Leave on the surface in the field & 19 & 10.8 & 11.5 & 0 & 13.8 & 13 \\
Pile outside field and burn & 7.1 & 2.7 & 11.5 & 7.3 & 1.7 & 0 \\
Throw in a hole and burn & 2.4 & 2.7 & 0 & 2.4 & 0 & 0 \\
Throw in a hole and bury & 52.4 & 45.9 & 44.2 & 29.3 & 29.3 & 8.7 \\
Feed cows & 0 & 0 & 9.6 & 4.9 & 8.6 & 17.4 \\
Throw far away & 0 & 10.8 & 7.7 & 0.4 & 13.8 & 26.1 \\
Pile outside farm and leave to rot & 0 & 0 & 16.2 & 0 & 39 & 1.7 \\
\hline N/A & 9.5 & & 0 & & 24.1 \\
\hline
\end{tabular}

A few farmers feed the rotten tubers to their animals. Once the tubers are fed to the animals, the bacteria find their way into the manure; because most farmers use cattle manure in their fields, the disease is spread even further in the farms. 


\section{Discussion and Conclusions}

The study aimed at collecting information on potato production in Kenya, potato marketing and production constraints, cultivar preferences, and prevalence and management of bacterial wilt in Meru, Bomet, and Nakuru counties. Important information was gathered through individual interviews with farmers.

There is a shortage of clean potato seed in Kenya and farmers depend on informal seed sources which include farm-saved (self supply), local markets or neighbours. Due to limited supply, the certified potato seeds are highly priced (Ayieko \& Tschirley, 2006). The informal system leads to use of poor quality seeds which often accelerates the spread of seed-borne diseases (Kinyua et al., 2001; Ng'ang'a et al., 2003).

Despite the problems in potato sector, farmers allocate more than $25 \%$ of their farms to potatoes possibly due to its importance as cash and food crop. In Molo and Elburgon, the allocation is more than 45\%. Wakahiu et al. (2007) found that farmers in Nyandarua district (another leading potato producer in Kenya) allocate about $50 \%$ of their farm to potato production. In Bomet district, farmers allocate less land to potatoes possibly because they grow tea; another lucrative cash crop. In addition, potatoes do not feature prominently in the diets of the local community. In contrast, potatoes are a major component of the diets of the local communities in Meru Central and Molo districts (McArthur, 1989).

Generally, farmers plant potatoes every second rainy season (Table 4). This is probably due to small farm parcels, limited choices of alternative crops as a result of unpredictable weather especially rainfall, and economic considerations due to a short potato growth period. However, this rotation is too short for proper management of soil fertility and plant diseases especially bacterial wilt. Wakahiu et al. (2007) found that $68.8 \%$ of farmers in Nyandarua practice a one season rotation. Furthermore, some farmers in the same county plant potatoes for 3-4 seasons consecutively.

In addition to potatoes, farmers grow other crops probably to meet various uses as well as hedge against the risk of crop failure. This was also observed by McArthur (1989) and Kaguongo et al. (2008). Among the crops, maize is grown by majority of farmers in all divisions surveyed. In this study, it was found that taste, yields and availability of market are the major factors determining potato cultivars grown in an area. This is in agreement with previous studies by Wakahiu et al. (2007). In another study, farmers in the main potato growing counties in Kenya ranked high yields as the most important criterion for growing a specific cultivar (Ng'ang'a et al., 2003).

There are regional differences in potato cultivars grown (Table 7). All farmers in Bomet Central and almost all farmers in Longisa divisions grow the red-skinned Dutch Robyjn. Wakahiu et al. (2007), Kaguongo et al. (2008) and Kaguongo et al. (2010) also found that farmers in these divisions grow Dutch Robyjn. This could be due to the specific processing market that farmers in this area supply. Kaguongo et al. (2010) found that the most commonly grown potato cultivar in Kenya was Tigoni (cultivated by $25.7 \%$ of farmers) followed by Nyayo (cultivated by $24.8 \%$ of potato farmers) and then Thima thuti (22.7\% of farmers). In addition, Tigoni was most popular in Nakuru County (grown by $61.9 \%$ of potato farmers and occupying $43.2 \%$ of potato area while Nyayo was grown by $37.1 \%$ of farmers on $16.3 \%$ of potato area in the same county. Tigoni and Nyayo are white-skinned and white-fleshed. The two have since been overtaken by Cangi (a white-skinned white-fleshed) farmer selection (Table 7). In Meru Central district, most farmers abandoned the red-skinned Ngure and Kerr's Pink (Table 9) for the equally red-skinned Asante (Table 7). It appears that despite changing the varieties, farmers did not change the skin colour. This indicates that market demand for a certain skin colour strongly affects variety choice.

Among the potato marketing constraints, price fluctuation is the most important (Table 11). Price fluctuations are due to seasonality in potato production leading to glut and lean times. Most farmers produce potatoes twice a year due to bimodal rainfall patterns in most potato growing areas (McArthur, 1989; Kinyae et al., 2004). The potato growers lack the ability to influence selling prices for their produce because of the poor keeping quality of potatoes and lack of adequate on-farm storage facilities. Over $80 \%$ of locally marketed potatoes go through brokers who shield the farmers from getting market information and in the process exploit them.

In the potato producing districts most of the access roads are impassable during wet season. This results in high transportation costs of the produce and a lowering of farm-gate prices by the traders as soon as the rains begin.

Among the production constraints, diseases are the most important. Bacterial wilt is the most common disease in all divisions surveyed followed by late blight (Table 13). The high prevalence of bacterial wilt in the potato growing areas can partly be due to planting of seeds from informal sources as well as inadequate rotation. Most farmers use seeds from informal sources (Table 6) partly due to high cost of certified seeds and/or lack of seeds (Ayieko \& Tschirley, 2006). The informal system leads to use of poor quality seeds and often accelerates the spread of seed-borne diseases (Ng'ang'a et al., 2003). This, in addition to lack of effective control method making 
bacterial wilt a major constraints headache to small scale potato farmers in Kenya. Although most farmers practice some form of crop rotation (Table 4), the cycle is often too short to eliminate bacterial wilt inoculum in the soil. In addition, farmers leave volunteer potato plants thereby rendering rotation irrelevant. According to Gildemacher et al. (2007), a crop rotation sequence where potatoes are grown once in every four seasons is required so long as no other Solanaceous crop is grown. However, in most potato growing areas in Kenya there is not enough land for such a long rotation (Riungu, 2011).

In addition to a suitable crop rotation scheme, removal of volunteers is extremely important (Gildemacher et al., 2007; The Organic Farmer, May 2012).

The PRA study has provided an insight into potato production in the Kenyan highlands. Most of the farmers are small scale and grow other crops in addition to potatoes. Potatoes are grown for both cash and food. There are regional differences in cultivars planted by farmers; cultivar preferences are mostly dictated by availability of market, yields and taste. Bacterial wilt is a major production constraint; this is managed through many cultural methods including crop rotation. However, all these methods have not been effective; there is need to breed for host resistance.

\section{Acknowledgement}

Due thanks go to the Alliance for a Green Revolution in Africa (AGRA) for funding this research.

\section{References}

Ateka, E. M., Mwang'ombe, A. W., \& Kimenju, J. W. (2001). Reaction of potato cultivars to Ralstonia solanacearum in Kenya. African Crop Science Journal, 9, 251-256. http://dx.doi.org/10.4314/acsj.v9i1.27646

Ayieko, M., \& Tschirley, D. (2006). Enhancing access and utilization of improved seed for food security in Kenya. Working paper No. 27/2006. Tegemeo Institute of agricultural policy and development, Egerton University, Kenya.

Champoiseau, P. G., Jones, J. B., \& Allen. C. (2009). Ralstonia solanacearum race 3 biovar 2 causes tropical losses and temperate anxieties. Madison, WI: American Phytopathological Society. Retrieved 25 June, 2010 , from http://www.apsnet.org/online/feature/ralstonia/

Champoiseau, P. G., Jones, J. B., Momol, T. M., Pingsheng. J., Allen, C., Norman, D. J., ... Caldwell, K. (2010). Ralstonia solanacearum Race 3 biovar 2 causing brown rot of potato, bacterial wilt of tomato and southern wilt of geranium. Madison, WI: American Phytopathological Society. Retrieved 25 June, 2010, from http://plantpath.ifas.ufl.edu/rsol/NRI_Project/Projectsummary.html

Crissman, C. C., McArthur, L., \& Carli, C. (1993). Seed potato systems in Kenya: A case study. CIP, Lima, Peru.

Durr, G., \& Lorenzl, G. (1980). Potato production and utilization in Kenya. CIP, Lima, Peru.

Fukuda, W. M. G., \& Saad, N. (2001). Participatory research in cassava breeding with farmers in Northeastern Brazil. Working document No. 14, Participatory Research and Gender Analysis Program Cali, Colombia.

Gildemacher, P., Demo, P., Kinyae, P., Nyongesa, M., \& Mundia, P. (2007). Selecting the best plants to improve seed potato. LEISA, 23,10-11.

GIZ-PSDA Kenya. (2011). Potato value chain. Improving the livelihood of Kenyan farmers by growing value, growing profits. Deutsche Gesellschaft für Internationale Zusammenarbeit (GIZ) and Promotion of Private Sector in Agriculture (PSDA). Nairobi, Kenya.

GOK. (2008). Legal notice No. 113 of 2008 (05 September 2008) (legislative supplement No. 40). Kenya Gazette Supplement, 64, 509-511.

Jaetzold, R., \& Schmidt, H. (1982). Farm management handbook of Kenya (Vol. 2, pp. 397-400). Nairobi, Kenya: Ministry of Agriculture.

Kabira, J. N. (1983). Storage and processing characteristics of three Kenyan potato varieties. M.Sc thesis. University of Nairobi, Kenya.

Kaguongo, W. P., Ng'ang'a, N. M., Muthoka, N., Muthami, F., \& Maingi, G. (2010). Seed potato subsector master plan for Kenya (2009-2014). Seed potato study sponsored by GTZ-PSDA, USAID, CIP and Government of Kenya. Ministry of Agriculture, Kenya. 
Kaguongo, W. P., Gildemacher, P., Demo, P., Wagoire, W., Kinyae, P., Andrade, J., ... Thiele, G. (2008). Farmer practices and adoption of improved potato varieties in Kenya and Uganda. Social Sciences Working Paper 2008-5. International Potato Centre (CIP), Lima, Peru.

Kinyae, P., Kirumba, W., \& Muchara. M. (2004). Irish potato market survey. Promotion of Private Sector Development in Agriculture (PSDA). Ministry of Agriculture, Nairobi, Kenya.

Kinyua, Z. M., Smith, J. J., Lung'aho, C., Olanya, M., \& Priou, S. (2001). On-farm success and challenges of producing bacterial wilt free tubers in seed plots in Kenya. African Crop Science Journal, 9, $279-285$. http://dx.doi.org/10.4314/acsj.v9i1.27649

Lemaga, B. (1997). Integrated control of potato bacterial wilt. Literature review and work plan 1995-1997. The African Highlands Initiative Technical Report. Series No. 3. International Centre for Research on Agroforestry (ICRAF), Nairobi, Kenya.

Martin, C., \& French, E. R. (1985). Bacterial wilt of potatoes caused by Pseudomonas solanacearum. CIP, Technical Information Bulletin, 13, 1-6. CIP, Lima, Peru.

McArthur, C. L. (1989). Evaluation, choice and use of potato varieties in Kenya. Social Science Department, Working Paper 1989-1. CIP, Lima, Peru.

Muo, K., \& Nderitu, J. H. (2010). Policy implementation and its economic impact on potato marketing value chain in Kenya. 1217-1225. Proceedings of the 12th KARI Biennial Scientific Conference. KARI Headquarters Nairobi, Kenya. 8-12 November, 2010.

Ng'ang'a, N. M., Kinyae, P. M., Walingo, A., Wakahiu, M. W., Kipkoech, D., Muhonja, L., \& Kabira, J. N. (2003). Potato production and technology dissemination in Kenya. Unpublished Report. .

Otipa, M. J., Wakahiu, M. W., Kinyae, P. M., Thuo, D. M., \& Kinoti, J. I. (2003). Survey of the bacterial wilt of potatoes caused by Ralstonia solanacearum and its spread in major potato growing areas of Kenya. Task Force Report. KARI, Nairobi, Kenya.

Riungu, C. ( 2011). No easy walk for potatoes. Horticultural News. The East African Fresh Produce Journal, 19, 16-17.

SPSS Inc. (2009). Statistical Package for Social Scientists. SPSS for Windows Release 18.0. 2009. SPSS Inc. 2009. Chicago, IL. Retrieved from www.spss.com

The Organic Farmer. (2012). Crop rotation reduces bacterial wilt. The Organic Farmer. The Magazine for Sustainable Agriculture in East Africa, 84,1-3.

Virk, D. S., \& Witcombe, J. R. (2007). Trade-offs between on-farm varietal diversity and highly client-oriented breeding: A case study of upland rice in India. Genetic Resources Crop Evolution, 54, 823-835. http://dx.doi.org/10.1007/s10722-006-9158-5

Wakahiu, M. W., Gildemacher, P. R., Kinyua, Z. M., Kabira, J. N., Kimenju, A. W., \& Mutitu, E. W. (2007). Occurrence of potato bacterial wilt caused by Ralstonia solanacearum in Kenya and opportunities for intervention. In 7th Triennial African Potato Association Conference (pp. 267-271). Alexandria, Egypt. 13-18 July 2007. African Potato Association, Kampala, Uganda.

Walingo, A. M., Alexandre, C., Kabira, J. N., \& Ewell, P. T. (1998). Potato processing in Nairobi Kenya: current status and potential for further development. Working paper No. 1997-6, International Potato Centre, Nairobi.

Witcombe, J. R., Joshi, A., Joshi, K. D., \& Sthapit, B. R. (1996). Farmer participatory crop improvement: I. Varietal selection and breeding methods and their impact on biodiversity. Experimental Agriculture, 22, 443-460.

Witcombe, J. R., Joshi, K. D., Gyawali, S., Musa, A. M., Johansen, C., Virk, D. S., \& Sthapit, B. R. (2005). Participatory plant breeding is better described as highly client-oriented plant breeding. I. Four indicators of client -orientation in plant breeding. Experimental Agriculture, 41, 299-319. http://dx.doi.org/10.1017/S0014479705002656 